\title{
The Art and Sustainable Aspects of Natural Dyeing in KANAWIDA Hand Drawn Batik (Green Batik)
}

\author{
July Hidayat $^{1}$ and Fatmahwaty ${ }^{2}$
}

\begin{abstract}
Indonesian batik has been recognized by UNESCO as the intangible cultural heritage of Indonesia. The ironic thing happened when Indonesian batik export is rejected by the market of European Union because of wearing artificial dyes and thus is categorized as eco unfriendly product. The chemical waste of artificial dyeing process can cause damage to environment and skin health of batik users. Therefore, the research and publication of natural dyeing materials and techniques in batik is needed to disseminate the techniques to craftmen and promote the use of green batik as a life style. In this paper, we discuss the art and sustainable aspects of natural dyeing in the making process of Kanawida Batik, one famous home industry of green batik in Banten and DKI Jakarta provinces. Using case study research method, we examine the art characteristics and implementation of sustainability requirements in the natural dyeing. The several results are: (1) knowledge about natural color sources and methods to produce it from natural materials, especially that are came from the richness and variety of Indonesian plants, (2) the manual and art characteristics of natural dyeing, (3) knowledge about how to implement sustainability in home industry of batik.
\end{abstract}

Keywords -green batik, natural dyeing, sustainable.

\section{INTRODUCTION}

$\mathrm{I}^{\mathrm{s}}$ ndonesian batik has been recognized by the United Nations Educational Scientific and Cultural Organization (UNESCO) as an intangible cultural heritage of Indonesia on 4th Session of the Intergovernmental Committee for the Safeguarding of the Intangible Cultural Heritage in Abu Dhabi, United Arab Emirates (UEE) on 2 September 2009 [9]. Export market of Indonesia to European Union for unknitting textiles including Batik was about $26 \%$ from total export amount to Europe [5]. But in fact, the ironic thing happens when Indonesian batik export markets declined by the European Union (EU) for wearing artificial dyes that its waste production damages the environment and health of the user skin, so that Indonesian batik is categorized as environmentally unfriendly products. Requirements of environmentally friendly products for the European market are set forth in the Economic Partnership Agreement [5]. After that the German Indonesian Chamber of Industry and Commerce (EKONID) in cooperation with Malaysian German Chamber of Commerce and Industry (MGCC) has initiated the program of Clean Batik Initiative (CBI) that has sought to develop eco-friendly batik production by giving train to the batik craftmen in Indonesia and Malaysia about cleaner batik [10]. This eco-friendly batik design has not been widely recognized by batik craftsmen in Indonesia. Books about ' green batik ', a term for Batik products that are environmentally friendly, are still hard to find. Therefore, the researches and publications on eco-friendly batik, especially discussing about the dyes and dying process are needed. This paper will discuss some of the research questions that determine the direction of the data searching that are: (1) what are the Indonesian natural plants that are used in the dying process of green batik? (2) How is the

\footnotetext{
${ }^{1}$ July Hidayat is with Departement of Interior Design, UPH, Tangerang, Banten, Indonesia. E-mail: julyhidayat@hotmail.com.

${ }^{2}$ Fatmahwaty is with Departement of Product Design, UPH Tangerang, Banten, Indonesia. E-mail: fatma_lie2000@yahoo.com.
}

processing of those natural plants to produce their natural color that is ready to be used in the dying process? (3) How is the dyeing process of batik when using the natural color that is efficient in energy consumption? Is its production has a broader impact in economy and social field besides of ecological one. This is questioning a sustainable characteristic of green batik (4) what is the art value of green batik.

Kanawida batik is a household scale of Batik industry that is located in the Pamulang area, South Tangerang City, Banten Province, Indonesia. The distinctiveness and excellence of Kanawida Batik products are in terms of the use of natural colors that do not harm the environment and the health of its users. The name 'Kanawida' is taken from Javanese Kawi language that means 'different color' to mention the colors of batik produced by tropical plants. Batik Kanawida is chosen as a case study of green batik because it is relatively consistent in producing eco-friendly batik for 6 years since its establishment in 2007 and has a mission regarding to sustainability which are: (1) preserve and develop the Batik cultural heritage of Indonesia and promote it to the younger generation, so the Indonesian younger generations will love their heritage, (2) protect the natural environment, (3) empower communities and help the economy of its surrounding environment, resulting in socio - economic impacts and therefore have a sustainable characteristics [7]. Due to utilize the wealth of Indonesian plants to produce its natural coloring, in 2009, Kanawida batik is awarded KEHATI Award from KEHATI foundation (Indonesian Biodiversity Foundation).

The purpose of this research is to understand how to make an ecological friendly batik, especially in terms of the art and technique of natural dyeing. The research intends to study how to process the tropical plant that become the source of natural colors, natural dyeing techniques and the advantages of natural coloring techniques from the art point of view. For the academic community and the craft section in product design department at School of Design, this research will 
provide knowledge or reference about ecological friendly crafts and initial inspiration for the development of batik craft specialization program. For a community of craftsmen, this study makes reference to the batik coloring technique using natural color of Indonesian tropical vegetation. As for the end-user of Batik, this research publication intend to promote the art and sustainable value of green batik, that by buying ecofriendly batik in the long run, people will maintain their own health and take part in reducing environmental destruction, take part in solving problems caused by chemicals pollution from industrial waste.

To answer the research questions which are the starting point of the study, the research team used the case study method. The advantage of this method is put in its ability to get a wide range of data or evidence from written documents, image documents, artifacts, deep interviews and direct observation of the phenomenon that is being developed at this time. The case study method can not be applied in past phenomenon as it is impossible to conduct a deep interview. The object of study is the home industry of Kanawida Batik. Although the approach used is qualitative, in the case study method, the researcher does not have to avoid commitment to a theoretical model as in the anthropological approach with its ethnographic method [2]. The case-study method requires the development of theory that will be used to guide the data collection and analysis. Stages of the research in the case study method will be discussed in detail in part II below.

\section{METHOD}

The way of analysis in case studies method is preceded by the development of certain theory. In this green batik research, the scope of theoretical studies are: (1) the meaning and characteristics of art, (2) natural dyeing techniques and materials that have been conducted by previous researchers, and (3) the characteristics of sustainable design products according to European Union recommendations.

The second stage of the case study is an investigation of the case. In the case of batik Kanawida, according to the research topic and formulation of the problem, the investigation was carried out on three things: (1) natural plant source of used color, (2) color processing techniques from natural plant until it was ready to be used in dyeing process, (3) dyeing processing technique itself. The next stage is to measure the data from the case study using the previously developed theory. Theories about the characteristics of art, knowledge about material and natural dyeing process that has been done by previous researchers and green batik requirements that meet the EU committee's recommendation will be compared with the investigation of material and green batik coloring techniques from Kanawida Batik. From this comparison, it can be analyzed how is the environmentally friendly dyeing process of batik which is eligible with environmental conservation prerequisits from the EU committee.

Terms of case study research object is a contemporary phenomenon, which are events that take place within this time period. It is implicated in the case that emerge in recent years and still continues to this day. This is required because one of the main collecting data methods in the case study research is in-depth interviews of the sources [2]. The data was collected through survey methods directly to the location of Kanawida batik workshop at Benda Street, Pamulang district, South Tangerang city, Banten province, to conduct in-depth interviews, batik visual documentations, observations and video documentation of the process of batik production. In-depth interviews will be conducted with the owner and designer of Kanawida batik, Mrs. Sancaya Rini.

The study design was made following the standard scheme of case study research [2] which includes the stages of theory development, case selection, retrieval and writing of field data, data analysis and modification, also the development implications of the theory in terms of color design. Scheme of the research that explain the analysis plot is shown in Figure 1 at the end of the discussion.

\section{RESULT AND DISCUSSION}

A. Natural tropical plant of indonesia that is used as the source of natural color in batik and its processing technique

Indonesia richness in natural resources is one of support to the textile dyeing process on natural color. Plants located in the tropics can produce a variety of dyes. Part of tropical plants such as roots, wood, bark, stems, leaves, flowers, seeds, sap and fruit have been used to produce natural dyes in batik. Variety of plant species in tropical has been used in beautifying Indonesian batik through the resulting color. Tropical plants commonly used in generating the primary color is secang (Caesalpina sp.), Indigo (Indigofera tinctoria) and sensitive plant (Mimosa pudica). Examples of plants that can be used as a natural dye of batik is turmeric (Curcuma domestica), rambutan (Nephelium lappaceum), mango (Mangifera indica), jengkol (Pithecelobium jiringa), avocado (Persea americana), mengkudu (Morinda citrifolia), angsana (Pterocarpus indicus), ketapang (Terminalia catapa), rib-fruited yellow mangrove (Ceriops candolliana) and achiote (Bixa orellana) [8]. Jackfruit plant (Artocarpus heterophyllu), mahogany (mahogany switenia) and Tegeran wood (Cudraina javanensis) is also often used in the textile industry [4]. At one of the tribes of Papua that is Marori Men-gey utilize plant like Vaccinium sp., M. Citrifolia , C. Domestica , Zyzygium sp., Ziziplus sp., Gmelina, M. indica to produce red, yellow and black colors [3]. Other plants that can produce color and used as a natural dye of batik is Peltophorum pterocarpum, Caesalpinia pulchherrima, Tectona grandis, Allium ascalonicum, Clitoria ternatea, Lawsonia inermis, Impatiens balsamina L, Cosmos caudatus, Areca catechu L., Hibiscus rosa - sinensis L., Uncaria Gambir, Cassia, Stelechocarpus burahol, Flacortia inermis, Spotode Campanulata Beau and Nyctanthes arbor tristis. In cooperation of PROSEA website data results (Plant Resources of South East Asia) and KEHATI, there is variety of plant species found in Indonesia categorized as a natural dye. Natural dyes are produced through the extraction process. The extraction is a process to produce color pigments by fermentation part of plant material soaked in water or by boiling part of plant material in 
water. After the extraction process, the next step is a filtering process which aims to separate the pulp with the water that has been colored. Color that appears in the natural dyeing batik fabrics range from red, yellow, blue, orange, purple and green. In addition to the colors mentioned above there are also new colors arise due to unexpected color combinations exploration process and the process of fixation to induce or amplify the color with other ingredients such as vinegar, alum, lotus and line. The process of extracting plants, barks or fruits to natural color of batik can be seen in Figure 2 .

\section{B. The Dying Process Of Batik Using The Natural Color}

At the beginning process of batik dyeing with natural dyes, provided fabric is firstly soaked in a special liquid to remove other substances that stick to the fabric so that the process will be uneven coloring. After soaking, air drying the fabric so that the fabric will be dry naturally. The first stage is to start drawing the fabric using a pencil. The drawing process can be directly or by follow the pattern behind the fabric. The next stage is using a tool called canting (the process of applying wax by using canting is called nglowong). This process is applying wax to produce a pattern frame according to the pattern that was created with a pencil before. Then the next step is to fill the pattern frame (ngisen -iseni), applying wax through the canting on the back surface of the fabric to clarify a copy of the first pattern frame (nerusi), cover the part (nembok) that are not colored or parts that are colored after another section with the wax by using big canting.

Fabric with applied wax then soaked with a special liquid. This will make natural dyes can be attached perfectly. Furthermore, the fabric is removed and soaked in a natural dye, stirring until evenly alternating set aside. After that, the fabric is removed and aerated with a clothesline and hang in place that is not exposed to direct sunlight. In order to get the long-lasting color, we must soak the fabric done many times until it reaches the desired color. The natural colors are not easily lost if we do the next phase that is locking color phase. It aims to strengthen the pose and color which are known as fixation. At this stage, the colored cloth that has been soaked with a liquid was given with vinegar or tawas or lotus or lime. Soaking in lime water will produce fabrics with colors that tend to be darker, while soaking with alum will result in lighter colors while immersion with lotus will concentrate the color. As a final touch, the fabric is removed, rinsed thoroughly, dried with aerated to dry and ironed. The process of dyeing, drying and washing wax can be seen in Figure 3.

\section{Art Characteristics Batik Dengan Pewarna Alami}

Art is the practice of creating perceptible forms expressive of human felling (Susan K. Langer). Art is an activity that uses flavor of feeling. Artistic value of natural color Batik comes from several factors, namely: (1) variation of similar plants that are a source of natural color itself, (2) the quality of water that is used to process natural color from plant, (3) expertise and a sense of individual crafts woman when working on the process of batik production, (4) the quality of the natural fiber fabric used, (5) the condition of the physical environment of production location, (6) how to hang batik in the open yard, (7) Batik pattern. These things will be discussed one by one in the below paragraphs.

The natural colors in Kanawida Batik are derived from plants and bark like: jelawi (Terminalia subspathulata), ketapang (Terminalia catappa), rambutan skin (Nephelium lappaceum), mangosteen (Garcinia mangostana), mango (Mangifera indica), roots of mengkudu (Morinda citrifolia), persimmon (Diospyros virginiana), secang (Caesalpinia sappan L.), marigolds flower (Cosmos caudatus), mahogany bark (Swietenia mahogany), angsana (Pterocarpus indicus) and leaves of teak (Tectona grandis). The herbs are grown in several original habitats, not only in Indonesia. For example: teak tree (Tectona grandis) has a native habitat not only in Indonesia, but also in India, Sri Lanka, Malaysia, Thailand, Myanmar, Laos and Cambodia. In Indonesia alone, the teak came from various regions in Java, along the northern coast of Java, such as Rembang, Blora, Groboragan and Pati, concentrated in tree provinces that are Central Java, Yogyakarta and East Java [6]. Teak trees from different regions have different specifications due to the different physical environments where it grows and its genetic structures which are resulted in various brown color schemes. Kanawida use natural dye color that is derived from the leaves of teak. When batik cloths dyed in brown color derived from the leaves of teak, they produce different brown colors on different fabrics because the leaves come from different teak trees that their seedlings also come from different areas. Differences in tree age when logging also affect the color produced. When the natural dye derived from fruits, different pluck period will result in different colors. That is why although batik fabrics dyed with colors derived from the same plant species, the result color can not be exactly the same as in artificial dyes production.

In the process of making the natural color, the plants are boiled for 15 minutes and then left overnight before it is finally filtered. The water used to soak and boil the herbs come from ground water. Batik Kanawida is located in Pamulang. The temperature of the ground water temperature in Pamulang is in the range 31-330 Celsius degree, while the range level of turbidity is between 11-61 NTU. The existence of this range temperature and turbidity affect the batik washing and dyeing process that uses water as a color solvent.

The third variable of artistic value is the skill of individual crafts women who worked on the batik production. In Kanawida batik, their craft women can apply the bee wax in the fabric without the guidance of any pattern, without depend on the pencil lines on the surface of the fabric. The craft women has such expert and experience that allow them to make Batik pattern without any stensils and they make patterns directly along with applying the beewax. The pattern making is done parallely with applying the beewax using their feeling. At that time, their good mood, their peaceful mind and the environment tranquility will affect the production of splendor motif and vice versa. In this way, every crafts woman has a distinctive lines character of drawing. Although they draw the same motif, the resulted form can not appear the same. It is not regarded as a deficiency but rather an advantage that gives unique art character on Kanawida batik. With the influence of 
indivual craft woman skill in drawing and applying wax, batik textiles can not be made exactly the same, but only similar between one to another; it is can not categorized as industrial product but art and craft.

Kanawida batik fabrics come from various natural fibers such as hemp, cotton, silk and banana leaves. Variations in the quality of the fabric will affect the absorption of color. For example: the quality of cotton derived from cotton seeds and hemp derived from cotton rods are different according to the degree of fabric subtlety, weaving density, thickness and level of hygroscopic (the ability to absorb sweat so fabric can be felt much cooler or hotter when used). When cotton fabrics used come from different cotton qualities, whether it is primis cotton (high quality cotton) or sada cotton (low quality cotton), dyes in the same basket contains of same natural color, the brightness and intensity of the resulting color will be different although their hue color is the same.

The process of making batik in Kanawida workshop is conducted in an open area that blends with the surrounding natural environment. Temperature and humidity in the summer and rainy seasons are different. For examples: temperature range in Pamulang during the rainy season is between 280-300 Celsius degree and the humidity is around $48-78 \%$. The coloring process consists of dyeing and drying activities which are performed repeatedly, at least 10 times of immersion. When the rainy days, the activities of dyeing and drying in the open air will be delayed and immersion-drying process may be not be completed in one day. By user experience, it had been proved that the color of natural dyes fabric can change when left in a relatively long time. It all depends on the kind of used fabric, the kind of used color material and the way of washing and dry the Batik. Changes in temperature and humidity of the location of Batik production have the potential to cause differences in color properties or resulting in the gradation of one hue, even when the cloth come from the same fabric and use the same color.

The natural color is sensitive to heat, especially such a sweltering heat from ultra-violet rays at noon. When two batik clothes are hung in different places with different ways, the first location is subject to direct sunlight and the second one is not, they will produce different colors of batik, although originating from the same fabric and color source. In the production process of Kanawida Batik, twenty pieces of scarves in 60 or $70 \mathrm{CM}$ wide and 200 CM long each can be dyed together to saving the water. Thus, there are conditions when 20 pieces of fabric are dyed and dried simultaneously and undergo a process of dyeing and drying over for alternately 10 times. When the natural fabrics are hung in different points of location of open yard, they won't exposured with the equal sun intensity. There are more rather hotter place, under the direct sunlight, and less shade ones. The complexity of making a hand-drawn batik result in the long period of production. One batik fabric with different level of complexity can be resolved within 7-14 working days, 7 hours a day. The different production period needed to solve a variety of fabric motifs cause unequal load in dyeing and drying processes. May be we can mentioned the average is around 20 pieces of fabric that can be dyed and dried once in the same time, but it can also less and more than 20 pieces in one run or production cycle. Thus, the process of ten times alternately dyeing and drying is varying in time. When in one dyeing process there are 20 fabric dyed and dried alternately for 10 times and at another one there are 25 fabric dyed and dried alternately for ten times, the first fabric of 20 pieces kloter will dyed and dried for the second time faster than the first fabric of 25 pieces kloter. In the kloter contains 20 fabrics, the first fabric is dipped and will be hung until all the 19 pieces left are dipped and hung as well, before it is dipped for the second time. While in the 25 pieces kloter, the first fabric will be hung longer until all the 24 pieces are handled. It means that in the bigger kloter, the first fabric is experienced more heat before its second color dipping. The intensity and position of the direct and indirect sun light during the drying process plus variety of pieces quantity in one kloter of dipping and drying cycles are potential to produce different brightness and intensity of colors, even when the fabrics use the same color source.

In the case of batik motifs, when the batik is worked whith no pattern, when the idea is belong to the creativity of the craft woman, of course the form patterns produced in one piece of batik can not be exactly the same from one module to another, of course in a whole, one fabric can not has the exact same pattern compare to another although they are meant to have the same pattern, especially because each craft woman has her draw line characteristic. The inconsistency of patterns in one fabric and the inconsistency of motifs in several fabrics are not seen as a disadvantage of natural Batik, but should be viewed as the value of its arts, the value of its craftmanship. The value of art in Kanawida Batik also appears through creativity of producing unusual batik motifs. It has developed the combination of natural colors with Javanese batik motifs, resulting in more modern and less informal look of Batik. It also has developed the combination of natural organic lines inspired from the Indonesian floral with Javanese batik motifs that also resulting with more contemporary batik that is hope more suitable to the younger and modern generation. This artistic value is sustainable in terms of penetrating the cultural value in modern form; reinvented the tradition.

\section{Sustainable Characteristics Of Natural Color Batik}

There are three things to be considered when craftmen want to make ecological friendly batik that has micro impact or limited in the context of batik itself (batik green), which are (1) natural material elements, (2) water saving, (3) other energy saving [1] like kerosene, gas or electricity used during the process of batik production. The fabrics used in the production of Kanawida batik are derived from nature like hemped, cotton fiber, silk, banana leaf and pineapple fibers. At this time the pineapple fiber is difficult to be found because it is produced in very small amounts. Clothing products are made from machinery woven fabric while scarf products are made by traditional and manual loom tool. At this time, Kanawida has sold more batik scarves in its outlet than another kind of batik function, so it has used more manual loom woven fabric. We also saw a lot of 
Kanawida Batik fabrics that is suitable for interior accessories such as table, chairs and bed covers as well as wall hanging tapestries. These interior accessories are also dominated by the manual loom fabric. This type of fabric has a rough texture that has artistic value of natural character. It is different with the machinery woven fabric that has finer surface of artificial and modern characters. It is also more effiecient in energy consumption as it is woven manually using no other energy than man power.

A community or organization of batik craftmen commonly anticipate the impact of environmental degradation when using artificial dyes by managing together the waste water processing facility that filtering toxic waste water of dyeing process. But this is not a total solution or a truly solution that really solve the problem. May be it can minimize the polusion process of their ground water but it still can not prevent the damage at the side of batik end user. When craftsmen still use artificial dyes, it will gradually damage the health of user sensitive skin. The comprehensive solution is stritcly switch to natural dyes because it does not cause damage to user skin health and it does not damage the soil and ground water at batik production site. In order to save water in the process of dyeing and wax washing, the dyeing and washing is carried out on a quite number of batik fabrics. In the process of Kanawida batik production, as its production capacity is still limited, it is arranged so that the quantity of batik processed in one cycle of dyeing and washing is around 20 pieces of scarves sized in 60 or $70 \mathrm{CM}$ wide and $200 \mathrm{CM}$ long. Thus, if one piece of batik fabric is completed in drawing process and wax application, the fabric is stored in advance to wait for another 19 ones. When 20 fabrics are collected, they are alternately dyed in the same basket of natural color liquid, then dried and finally washed in order to remove wax also using the same basket of hot water to efficiently water consumption.

When deals with other energy sources, the karosene is used to melt and heat the bee wax along the hand drawn process and bee wax application. The electricity is used for the water pumps while the gas is used for boiling water when dipping color and washing wax material. In order to save fuel oil, one stove is used by the 4 craftmen along 7 hours a day during the wax application process. In 4 days, the process had required less than 2 liters of kerosene. While in the case of gas that is used to boil the natural color and water for wax cleaning, the gas is saved by doing the boiling and washing activities once in two or three weeks, waiting for minimum 20 pieces of batik are collected to be dyed and washed together at the same time. By doing so, the company had tried to save the water, also the other energy like gas consumption.

\section{E. Sustainable Characteristics Of Home Industry Kanawida}

Sustainability in the context of product design is environmentally friendly aspects in the macro level [1] A home industry that produces a product declared as sustainable must fulfill not only the properties of environmentally friendly requirements, for example are made from natural materials and energy efficient, but also its production process must have broader impact in economic, social and cultural field in such a way that enables components involved in the production process to exist continuosly. Kanawida batik production has given the opportunity for mothers and younger generation, girls and women from its surrounding environment to learn and work as batik craft women so they can increase their household income by taking the side job or the main job of making natural batik. By doing it, the also have been realized about the environment issue and learn to apply the energy efficiency in making batik. Hopefully they can implement the same principal of saving energy in their household. Batik Kanawida also provide training for street children to learn to make green batik, so besides of being introduced to their cultural heritage, they also taught about the skill of making batik that can be used to make money. By teaching people about how to make green batik, Kanawida batik has taken part to grow awareness of protecting the environment among the younger generations. It is a socio - economic responsibility that has been done by Kanawida batik to its social environment.

One of the Kanawida breakthroughs that is considered to continue and deliver the value of traditional Indonesian cultural among the younger generations, especially the Javanese batik culture, is a combination of simplification Javanese motif with natural dyes. This produces a unique batik that has economic value. During this time, Yogyakarta and Solo are famous for becoming the center of Java Negarigung culture (the term follows the mapping of Javanese culture made by antropologist Kuntjaraningrat) that used to use dark and light brown colors in batik, in contrast to the coastal Java batik that commonly appears with bright colors. Kanawida batik made the breakthrough by promoting the Java typical motif in soft and calm of natural color scheme. Kanawida had done experimentation of applying the Java batik motif 'lereng' on the light blue color (indigo) of natural fabrics with interesting texture that combine a more dense weaving with the less one. The samples of Kanawida batik can be seen in Figure 4. We take it as an innovation because the value of Javanese culture is not just represented phisically through the Java batik motif but through the more sublime way of natural color character. The soft and calm character of natural color represents the humble character and unity with nature attitude that is also the value of Javanese culture. Simplifying the Java batik motif with softer natural colors will reach a wider market of younger and modern generation. In addition, the richness of Indonesia biodiversity are represented in many forms of floral abstraction using organic lines, forms and colors, strengthening the natural image of Kanawida batik. The curving form of organic and continuous lines represents the natural character of plants and casual image. Thus, Kanawida natural character is not generated merely from its fabric and color but also derived from the applied motif. That is called a redundancy. It is happened when one element character is strenghten by another as they talking in the same page about the same image.

When the applied motifs are created in the more modern image and made in the form of a simple casual clothes and scarves, batik as Indonesian cultural heritage can enter the range of younger buyer taste that is more modern. Thus, batik will not only use by the older 
generation in official events but also by young people in the more relaxing ambience of daily life activities. It is the effort of Kanawida to continue the cultural values to younger generation not by taking conservation approach but by dialoguing the value of tradition with environmental friendly awareness and the modern spirit of age (zeitgaist) of currently users in the big city like Jakarta. Actually when the traditional value is dialogued with modern one forming a double code in a product design, the value of Kanawida batik has been developed in more contemporary way. The value of contemporary design is reinventing tradition. When we try to reinvent our tradition, we don't treat it in the context of cultural conservation, but we give it our new interpretation. We give the tradition new meaning by dialoguing the past value with the present one, so that it can also be understood by consumers derived from modern culture. Thing that is always been questionable or critized in this case is whether the batik craftmen would undermine their cultural values when they do not follow the traditional batik pattern. It is commonly critized by those who pro with cultural conservation approach. On the other side, I believe that the value of cultural identity is not a stable value that is permanent and unchanging like a standard general pattern but it always in the process of becoming and always demanding for being reinterpreted by its actors. The hybridity of traditional values with more modern and universal value is a necessity in order to make the cultural richness of Indonesian batik can be accepted, absorbed and comprehended by people from different time and space.

The energy saving is managed by saving the transportation [1] of gathering plants and bark used for making natural colors. The owner of Kanawida batik has planted various plants that are used for sources of natural dyes in her wide yard, close to the location of batik workshop. Fruit used as sources of natural dyes that processed to make liquid for dyeing batik are collected from the fallen fruits, not from the fruits that are still bounded to their trees. They also collect the 'garbage' of fruits. They collect fruits that had already been rejected by the quality control department of food industries that sell or use fruits. By utilizing and empowering waste into natural dye batik, Kanawida has turned waste material into a blessing. Through bins of fruit, they can produce such eco-friendly batik and furthermore, the batik production has increased the income of young woman and mothers who lived in surrounding area of Kanawida workshop and work at Kanawida as a full time or part time craft woman.

\section{CONCLUSION}

The main issues in the green industry is energy saving that is saving raw materials and energy consumption in order to procure the sustainability of raw materials and energy supply for future generations. There are three things that must be done by one industry to become a green one, which are (1) reducing energy consumption, (2) efficiency of energy use, (3) minimize the toxic waste from the production process. In Kanawida batik, the consumption of water, gas and kerosene is saved first by doing the production process that requires those regular fuels only in a certain period for a certain amount of batik quantity. Batik products are not processed one by one but by 20 products managed in one cycle of production process. The second way of saving fuel is done by combining several tools used by craftsmen with a ratio of $4: 1$. It's meant that 1 tool is used by 4 craftsmen. Toxically batik waste production that comes from artificial coloring had been eliminated because Kanawida batik has already used natural dyes from tropical plants. If there is still thing that can be improved is in term of wax used in batik drawing process. Kanawida batik has already used bee wax to replace fuel - oil wax like paraffin, but as a natural and biodegradable wax alternative that has a lower melting point for saving energy, Kanawida can use a plant wax like palm wax and soya wax.

In addition to reducing health and environmental impact in a micro-scale, in the context of the use of green batik itself, Kanawida batik production has a macro impact in a longer time, in the field of ecology, economy and social. Kanawida batik creates jobs for women who live around the neighborhood to get extra income by becoming batik craft women, so they have the opportunity to work and help their family economy. Kanawida also taught the street child about making batik so they have skill, eco-friendly awareness and knowledge about their culture heritage. Thus, Kanawida batik, in certain level, has already had the green and sustainable characters. Further study is needed to understand how to measure the degree of a green industry in 6 main areas, namely energy, transportation, waste or recycling, water, company supplies and green or cleaning products, to be able to provide specific input to Kanawida Batik home industry, to improve its green and sustainable quality.

Although we have discussed the uncertainty factors in the production of natural dyes and hand-drawn batik and take it rather as an advantage of art value than disadvantage, Kanawida batik need to consider a bigger controlled in their production process. We think that they are need to make a more standardized operating procedure, taking notes for all the production process and amount of used material in order to grow and serve a bigger demand. It will become like design characteristic that putting feet in two fields, keeping balance between art and engineering, between beautiful and functional, between becoming genuinely artistic, orderly efficient.

\section{ACKNOWLEDGEMENT}

We would like to thank Mrs. Sancaya Rini, the owner and designer of Kanawida Batik who gave us a chance to learn about the art of natural dying. We has appreciated her interest in the richness of Indonesia biodiversity and her vision to build the community of green batik craft men to be able to speak louder about green batik campaign and make a greater impact of it. By sharing her effort on Knawida batik, we'd like to support her mission of promoting green and sustainable batik industry.

\section{REFERENCES}

[1]. Mackenzie, Dorothy, "Green Design. Design for the Environment," London: Laurence King Publishing, 1991.

[2]. Yin, Robert K., "Case Study Research. Design and Methods," Thousand Oaks, California: Sage Publication, 1994.

[3]. Harbelubun, Antonius Etus, Elisa Markus Kesaulija, Yohanes Yoseph Rahawarin, Tumbuhan Pewarna Alami dan 
Pemanfaatannya secara Tradisional oleh Suku Marori Men-gey di Taman Nasional Wasur Kabupaten Merauke, "Biodiversitas", Vol. 6, No. 4, October 2005, p. 281-284.

[4]. Prayitno, Endro Kismolo, Nurimaniwati, Proses Ekstraks Bahan Pewarna Alam dari Limbah Kayu Mahoni, Proceeding of "Pertemuan \& Presentasi Ilmiah Penelitian Dasar Ilmu Pengetahuan \& Teknologi Nuklir", Yogyakarta: P3TM-Batan, 2003.

[5]. Government of Indonesia Ministry of Trade, Delegation of the European Union, "Invigorating the Indonesia-EU Partnership: Towards a Comprehensive Economic Partnership Agreement", http://unieropa.org/eng/down/8913072012154316/, cited in October 2013.

[6]. Pusat Inventarisasi \& Statistik Kehutanan Departemen Kehutanan and Direktorat Statistik Pertanian Badan Pusat Statistik, "Potensi Hutan Rakyat Indonesia 2003", http://www.dephut.go.id, released in 2004, cited in October 2013.

[7]. Rini, Sancaya, "Batik Kanawida Vision, Mission, Programs and Characteristics", http://www.kanawidabatik.com, direct interview is done in October 2013, the website is cited in October 2013.

[8]. Rini, Sancaya, Sugiarti, Melani Kurnia Riswati, "Pesona Warna Alami Indonesia", www.kehati.or.idimagespublikasiBuku01_ Pesona\%20Warna\%20Alam\%20Indonesia_final.pdf, cited in October 2013.

[9]. Website administrator, "Fourth Session of Intergovernmental Committee-Abu Dhabi, United Arab Emirates, 28 September to 2 October 2009", http://www.unesco.org/culture/ich/en/4COM, cited in October 2013.

[10]. Website administrator, "Background, Programmes and Objectives Overview of Clean Batik Initiative", http://www.cleanbatik.com, cited in October 2013.

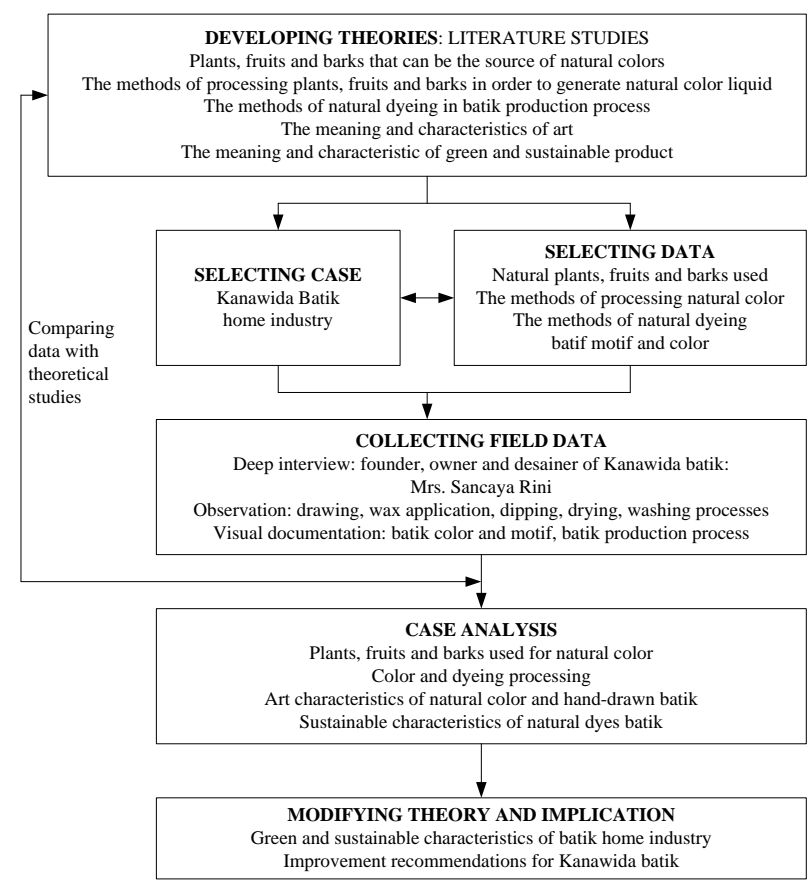

Figure. 1. Schematic of Case Study Research Method Picture source: Survey to Kanawida Workshop in 2013

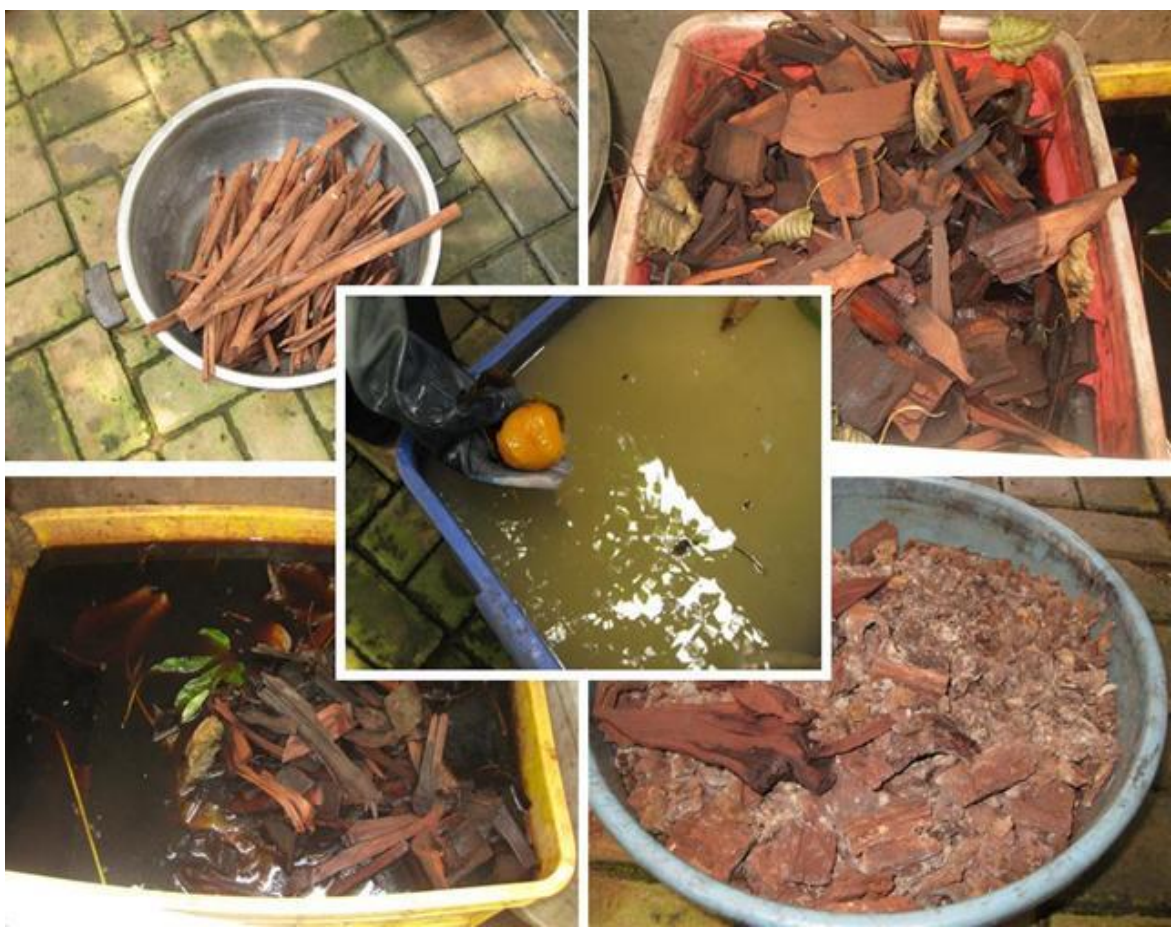

Figure. 2. Natural Material Used in Kanawida Workshop and Its Soaking Process Picture source: Survey to Kanawida Workshop in 2013 

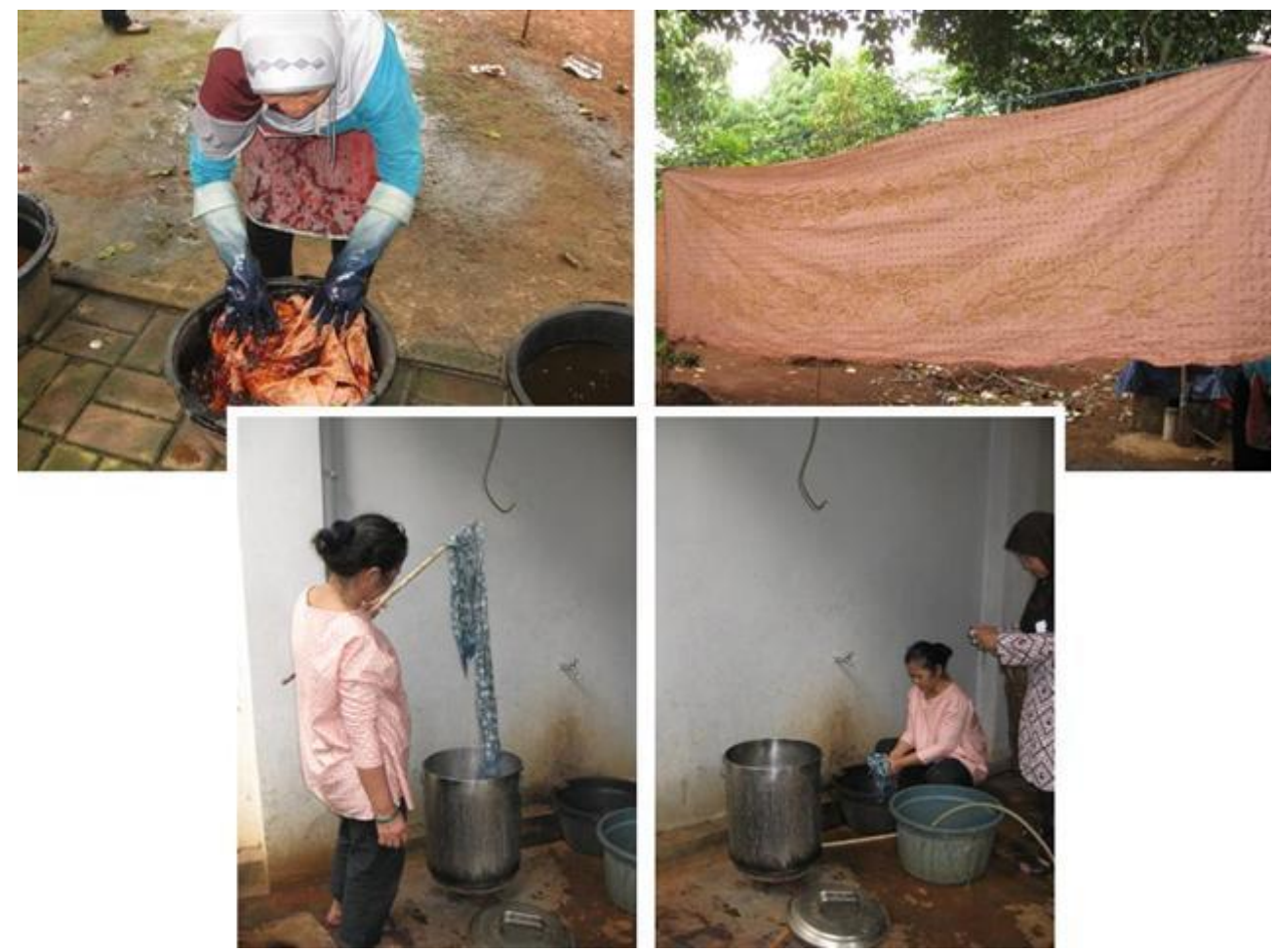

Figure. 3. Natural Dyeing Process in Kanawida Workshop Picture source: Survey to Kanawida Workshop in 2013
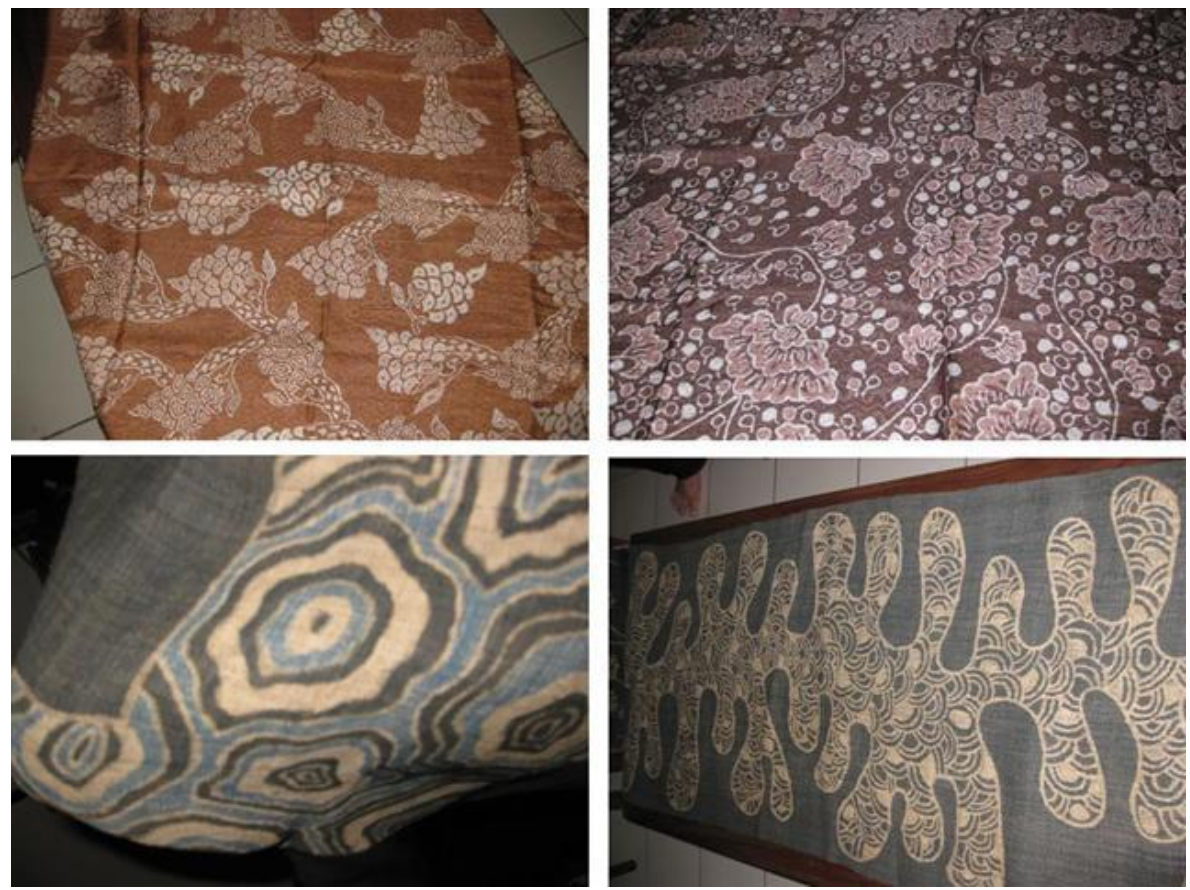

Figure. 4. Kanawida Batik Picture Source: Survey to Kanawida Workshop in 2013 